\title{
Turmeric Powder: Potential Alternative to Antibiotics in Broiler Chicken Diets
}

\author{
Eddiemar B. Lagua ${ }^{1}$, Keiven Mark B. Ampode ${ }^{2 *}$
}

${ }^{1}$ Department of Animal Science, College of Agriculture, Central Mindanao University, 8710, Philippines; ${ }^{2}$ Department of Animal Science, College of Agriculture, Sultan Kudarat State University - Lutayan Campus, 9803, Philippines.

\begin{abstract}
The gradual increment of the human population resulted in an increased demand for animal protein in developing countries. To satisfy the need for animal protein, synthetic antibiotics were incorporated into broiler chickens' diets to stimulate growth and rapidly increase production performance. This is a significant problem since the resistance of antimicrobial can be derived from antibiotics' abusive usage. The antibiotic immunity is of great public health concern because the antibiotic-resistant bacteria linked with the animals may be infective to humans, easily transmitted through food chains to humans, and widely disseminated via animal waste in the environment. These can cause complex, which somehow prolonged human infections leading to higher healthcare costs and often death. There is an urgent need for the agricultural industry to develop strategies to substitute antibiotics for food-producing animals, especially poultry and livestock. Turmeric (Curcuma longa Linn.) is one of the many medicinal herbs promising agricultural products as natural feed additives in poultry diets. It is the primary source of phenolic compounds such as curcumin, bisdemethoxycurcumin, demethoxycurcumin, and tetrahydrocurcuminoids. Several trials of the utilization of turmeric in poultry have been conducted using the in vitro and in vivo methods, and it was found out that turmeric and its derivatives have antimicrobial properties. The use of turmeric powder as feed additives and supplements have been recommended as an alternative to antibiotics for broiler chicken production. The purpose of this review is to discuss the antimicrobial property of turmeric powder and its effect on broiler chicken in terms of performance and meat quality.
\end{abstract}

Keywords | Curcuma longa, Curcumin, Antimicrobial, Antioxidant, Meat quality

Received | February 07, 2021; Accepted | April 30, 2021; Published | July 01, 2021

*Correspondence | Keiven Mark Ampode, Department of Animal Science, College of Agriculture, Sultan Kudarat State University - Lutayan Campus, 9803, Philippines; Email: keivenmarkampode@sksu.edu.ph

Citation | Lagua E, Ampode KM (2021). Turmeric powder: potential alternative to antibiotics in broiler chicken diets. J. Anim. Health Prod. 9(3): $243-253$.

DOI | http://dx.doi.org/10.17582/journal.jahp/2021/9.3.243.253

ISSN | 2308-2801

Copyright $(2021$ Lagua and Ampode. This is an open access article distributed under the Creative Commons Attribution License, which permits unrestricted use, distribution, and reproduction in any medium, provided the original work is properly cited.

\section{INTRODUCTION}

$\mathrm{P}$ oultry raising has undergone a paradigm shift in structure and activity, transforming itself into a major commercial enterprise from a mere backyard sector (Dalal and Kosti, 2018). It is very popular compared with some livestock industries such as swine and cattle because it enjoys a relative advantage on the ease in management, wide acceptance of its product, quick and higher returns to capital investment (Dumaup and Ampode, 2020). With the gradual increment of the human population, it is also expected that demand for poultry meat and its by-products will increase in the nearest future. Thus, to satisfy the demand for poultry products, synthetic antibiotic growth promoters (AGPs) were incorporated into animal feed to stimulate growth, rapidly increase productivity, reduce the production cost, reduce feed efficacy, and minimize mortality preventing infections (Van den Bogaard and Stobberingh, 2000). This is a significant problem since the resistance of antimicrobial can be derived from antibiotics' abusive usage (Landers et al., 2012; WHO, 2012; Guil-Guerrero et al., 2017). The abusive use of antibiotics had indirect adverse effects on human health because of residues in chicken meat, milk, and eggs (Guetiya-Wadoum et al., 2016). Moreover, antibiotic immunity is of great public health concern because antibiotic-resistant bacteria associ- 
ated with the animals may be pathogenic to humans, easily transmitted through food chains to humans and widely disseminated via animal waste in the environment (ManyiLoh et al., 2018). Hence, the use of antibiotics as a growth promoter was totally banned in the European Union since January 2006.

The worldwide ban on the use of synthetic antibiotics and the consumers augmented awareness triggered a need for natural and safe feed additives to obtain better production results of farm animals (Ortserga et al., 2008; Alagawany et al., 2016). Hence, the use of prebiotics, probiotics, essential oils, and the inclusion of various medicinal herbs into poultry diets as an alternative to synthetic antibiotics has been investigated to maximize poultry's production performance. These feed additives become poultry raisers' interest because of their potential as antioxidant, antibacterial, digestive, and metabolic enhancing effects (Durrani et al., 2006; Attia et al., 2017). The ideal antibiotic alternatives should have the same mechanism and beneficial effects as AGPs to ensure optimum production performance and increase nutrient availability (Lillehoj et al., 2018). The utilization of botanical compounds has been reported to be potential alternatives to antibiotics for poultry production (Nasir and Grashorn 2010; Nouzarian et al., 2011; Attia et al., 2017).

One of the many medicinal herbs promising agricultural products as natural feed additives in poultry diets is Turmeric (Curcuma longa Linn.) from the Zingiberaceae family (Figure 1). In the Philippines, turmeric is commonly known as "luyang dilaw". It is a perennial plant with a short stem and large oblong leaves, and it bears ovate, pyriform, or oblong rhizomes, which are often branched and brownish-yellow in color (Daneshyar et al., 2011). It is primarily utilized to improve food palatability, enhanced food appearance, food preservation (Attia et al., 2017), traditionally used as medicine ( $\mathrm{Li}$ et al., 2011), and one of the most popular dietary supplements in the world (Andrew \& Izzo, 2017). Moreover, turmeric is one of the primary sources of phenolic compounds such as curcumin, bisdemethoxycurcumin, demethoxycurcumin, and tetrahydrocurcuminoids (Kiuchi et al., 1993; Al-Sultan, 2003; Sadeghi, 2012). These bioactive compounds are yellowish turmeric pigments and have antioxidative, anticarcinogenic, anti-inflammatory, nematocidal activities, and antihepatotoxic (Nishiyama et al., 2005). It also controls against coccidiosis (Allen et al. 2002), mutagenicity, and hepatocarcinogenicity induced by aflatoxin (Soni et al., 1997, Ahmadi, 2010; Attia et al., 2017). However, limited literature has been published on turmeric utilization as a natural growth promoter in broiler chickens. Thus, a review has been made to present turmeric's potential in broiler chicken production, nutrition, and health.
Active Chemical Components of Turmeric POWDER

Turmeric contains a high level of beneficial phenolic compounds (curcuminoids) and terpenoids (sesquiterpenes). The main curcuminoids of the rhizome are curcumin, demethoxycurcumin, and bisdemethoxycurcumin. Whereas ar-turmerone, $\alpha$-turmerone, and $\beta$-turmerone are the major ketonic sesquiterpenes of turmeric essential oil. These compounds have been reported to have antibacterial, antioxidant, anti-inflammatory, antihepatotoxic, anticarcinogenic, and hypocholesterolemic activities (Nishiyama et al., 2005; Daneshyar et al., 2011; Li et al., 2011; Abou-Elkhair, 2014; Alagawany et al., 2016).

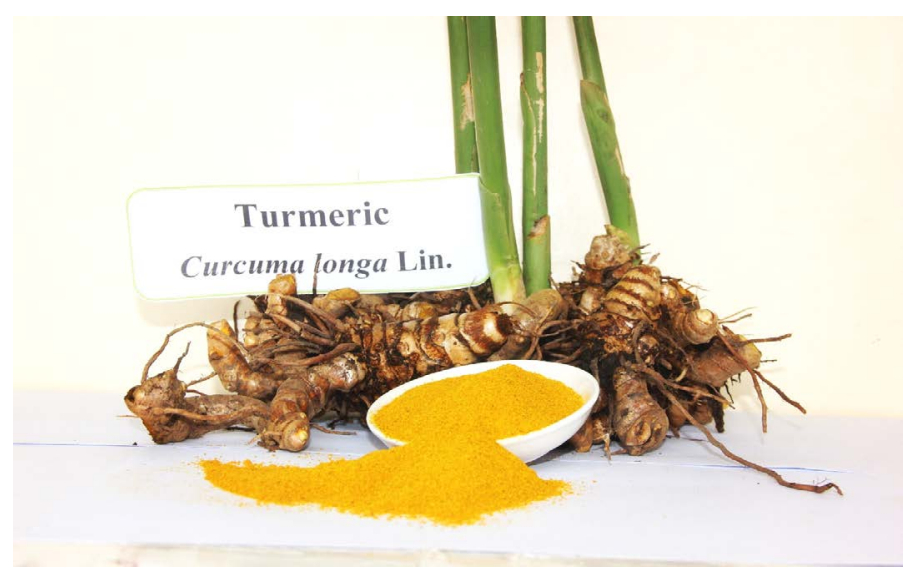

Figure 1: Fresh turmeric rhizome and powder Photos by Keiven Mark B. Ampode and Arbaya M. Zacaria, College of Agriculture, Sultan Kudarat State University Lutayan Campus

Curcumin is the major bioactive component of turmeric powder (Pawar et al., 2014), about $80 \%$ of the total curcuminoids (Ashraf and Sultan, 2017). It can reach up to 6.8-7.3\% of the product as reported by Paul et al. (2016). Curcumin is hydrophobic phenol and is responsible for the turmeric's orange-yellow color (Tanzeela et al., 2015; Choudhury, 2019). The primary issue of curcumin is its poor absorption in the small intestine. Nevertheless, novel methods to increase its bioavailability and curcumin's efficacy in influencing the functionality and improving gut health may be associated with a concentration in the intestine due to its poor absorbability (Lopresti, 2018).

Prasad and Aggarwal (2011) reported that turmeric originated in India is considered the best in the world's curcumin content basis. However, the variation of curcumin content of turmeric from various states of India was observed by Geethanjali et al. (2016). This variation may affect the quality of the turmeric and its efficacy to animal performance (Table 1 and 2). Nonetheless, a prediction model was developed to quantify environmental factors for predicting and optimizing curcumin content for commercial cultivation (Abdul et al., 2016). 
Table 1: Effect of turmeric powder on broiler performance and meat quality raised in normal condition

\begin{tabular}{|c|c|c|c|c|}
\hline $\begin{array}{l}\text { Breeds and Duration } \\
\text { of Exposure }\end{array}$ & Methodology & Findings & $\begin{array}{l}\text { Recommended } \\
\text { TP Inclusion }\end{array}$ & References \\
\hline $\begin{array}{l}\text { 1-day-old Ross- } 308 \\
\text { broiler, } \\
\text { 42-days of trial }\end{array}$ & $\begin{array}{l}\text { Total } 350 \text { chicks in seven die- } \\
\text { tary treatments: control, } 0.2 \% \\
\text { TP, } 0.4 \% \mathrm{TP}, 0.6 \% \mathrm{TP}, 0.8 \% \mathrm{TP} \\
1 \% \mathrm{TP}, \& 1000 \mathrm{ppm} \text { antibiotic } \\
\text { (unnamed) }\end{array}$ & $\begin{array}{l}\uparrow \text { DHA fatty acid } \\
\downarrow \text { TBARS in thigh meat, satu- } \\
\text { rated fatty acids of breast meat } \\
\text { in } 0.8 \% \& 1 \% \text { TP. } \\
\leftrightarrow \text { TBARS in breast meat, } \\
\text { saturated fatty acids of thigh } \\
\text { meat }\end{array}$ & $0.2-0.8 \%$ & $\begin{array}{l}\text { Urusan and Bo- } \\
\text { lukbasi } 2020\end{array}$ \\
\hline $\begin{array}{l}\text { 1-day-old Ross } \\
\text { broiler, } \\
\text { 56-days of trial }\end{array}$ & $\begin{array}{l}\text { Total } 200 \text { chicks in five dietary } \\
\text { treatments: control, } 0.25 \% \text { TP, } \\
0.5 \% \text { TP, } 0.75 \% \text { TP, \& } 1 \% \text { TP }\end{array}$ & $\begin{array}{l}\uparrow \text { BWG \& FCR in } 1 \% \text { TP } \\
\text { compared other TP groups } \\
\leftrightarrow \text { BWG, FCR \& blood lipid } \\
\text { profile in } 1 \% \text { TP and control }\end{array}$ & $1 \%$ & $\begin{array}{l}\text { Ekine et al. } \\
2020\end{array}$ \\
\hline $\begin{array}{l}\text { 1-day-old Arbor-acre } \\
\text { broiler, } \\
\text { 29-days of trial }\end{array}$ & $\begin{array}{l}\text { Total } 108 \text { chicks in three dietary } \\
\text { treatments: control, } 0.5 \% \text { TP, \& } \\
1 \% \text { TP }\end{array}$ & $\begin{array}{l}\uparrow \mathrm{BWG} \text { in } 1 \% \mathrm{TP} \\
\downarrow \mathrm{FI} \text { in } 0.5 \% \mathrm{TP}, \mathrm{FCR} \text { com- } \\
\text { pared to control }\end{array}$ & $1 \%$ & Daramola 2020 \\
\hline $\begin{array}{l}\text { 1-day-old broiler, } 42- \\
\text { days of trial }\end{array}$ & $\begin{array}{l}\text { Total } 300 \text { chicks in six dietary } \\
\text { treatments: control, with antibiot- } \\
\text { ic, } 0.25 \% \mathrm{TP}, 0.5 \% \mathrm{TP}, 0.75 \% \mathrm{TP} \text {, } \\
\& 1 \% \mathrm{TP}\end{array}$ & $\begin{array}{l}\uparrow \mathrm{BWG}, \text { Lactobacilli count } \\
\downarrow \mathrm{FCR}, \text { C. perfringes counts } \\
\leftrightarrow \mathrm{FI}\end{array}$ & $0.5 \%$ & $\begin{array}{l}\text { Ahlawat et al. } \\
2018\end{array}$ \\
\hline $\begin{array}{l}\text { 1-day-old Cobb- } 500 \\
\text { broilers, } \\
\text { 32-days of trial }\end{array}$ & $\begin{array}{l}\text { Total } 360 \text { chicks in six dietary } \\
\text { treatments: control, } 0.5 \% \text { TP, } \\
0.75 \% \text { TP, } 0.5 \% \text { ginger powder, } \\
0.75 \% \text { ginger powder, } \& 0.5 \% \\
\text { ginger powder }+0.5 \% \text { TP }\end{array}$ & $\begin{array}{l}\uparrow \mathrm{BWG}, \mathrm{FCR}, \\
\leftrightarrow \mathrm{FI}, \text { weight of offal, hema- } \\
\text { tology }\end{array}$ & $0.75 \%$ & Kafi et al. 2017 \\
\hline $\begin{array}{l}\text { 1-day-old Hubbard } \\
\text { broiler, } \\
\text { 25-days of trial }\end{array}$ & $\begin{array}{l}\text { Total } 252 \text { chicks in six dietary } \\
\text { treatments: control diet, } 0.05 \% \\
\text { TP, } 0.1 \% \text { TP, } 0.2 \% \text { TP, } 0.1 \% \\
\text { MOS \& } 50 \text { ppm CTC }\end{array}$ & $\begin{array}{l}\uparrow \mathrm{EPEI} \text { in } 0.1 \% \mathrm{TP} \\
\downarrow \mathrm{FI} \text { in } 0.2 \% \mathrm{TP} ; \mathrm{FCR} \text { in } 0.1 \% \\
\& 0.2 \% \mathrm{TP} \\
\leftrightarrow \mathrm{BWG}, \mathrm{MQ}\end{array}$ & $0.1 \%$ & Attia et al. 2017 \\
\hline $\begin{array}{l}\text { 1-day-old male Ross } \\
308 \text { broiler, } \\
42 \text {-days of trial }\end{array}$ & $\begin{array}{l}\text { Total } 200 \text { chicks in four dietary } \\
\text { treatments: control, } 0.25 \% \text { TP, } \\
0.5 \% \text { TP, \& } 0.75 \% \text { TP }\end{array}$ & $\begin{array}{l}\uparrow \text { Protein (numerical) of thigh } \\
\text { meat; } \\
\downarrow \text { Blood triglyceride, saturated } \\
\text { fatty acid of thigh meat } \\
\leftrightarrow \mathrm{pH}, \text { Dry Matter, Ash, tri- } \\
\text { glyceride of thigh meat }\end{array}$ & - & $\begin{array}{l}\text { Daneshyar et al. } \\
2011\end{array}$ \\
\hline $\begin{array}{l}\text { 1-day-old Vencobb } \\
\text { broiler, } \\
\text { 42-days of trial }\end{array}$ & $\begin{array}{l}\text { Total } 280 \text { chicks in seven dietary } \\
\text { treatments: control, } 0.1 \% \text { Aloe } \\
\text { vera } \text { Powder, } 0.2 \% \text { Aloe vera Pow- } \\
\text { der, } 0.1 \% \text { TP, } 0.2 \% \text { TP, } 0.1 \% \text { Aloe } \\
\text { vera Powder }+0.1 \% \text { TP, } \& 0.2 \% \\
\text { Aloe vera } \text { Powder }+0.2 \% \text { TP }\end{array}$ & $\begin{array}{l}\downarrow \text { FCR at first week } \\
\leftrightarrow \text { BWG, FI, FCR }\end{array}$ & $0.1 \%$ & $\begin{array}{l}\text { Mehala and } \\
\text { Moorthy } 2008\end{array}$ \\
\hline $\begin{array}{l}\text { 1-day-old Ross } \\
\text { broiler, } \\
\text { 49-days of trial }\end{array}$ & $\begin{array}{l}\text { Total } 200 \text { chicks in four dietary } \\
\text { treatments: control, } 0.25 \% \text { TP, } 5 \% \\
\text { TP, \& } 0.75 \% \text { TP }\end{array}$ & $\begin{array}{l}\downarrow \text { Abdominal fat } \\
\leftrightarrow \text { FI, BWG, FCR, CSCI }\end{array}$ & $0.25 \%$ & $\begin{array}{l}\text { Emadi and } \\
\text { Kermanshashi } \\
2006\end{array}$ \\
\hline $\begin{array}{l}\text { 1-day-old broiler, } \\
35 \text {-days of trial }\end{array}$ & $\begin{array}{l}\text { Total } 160 \text { chicks in four dietary } \\
\text { treatments: control, } 0.25 \% \mathrm{TP} \text {, } \\
0.5 \% \mathrm{TP}, \& 1 \% \mathrm{TP}\end{array}$ & $\begin{array}{l}\uparrow \mathrm{BWG} \text {, dressing percentage, } \\
\text { thigh \& breast weight in } 0.5 \% \text {, } \\
\downarrow \text { FCR in } 0.5 \%, \text { FI compared } \\
\text { to control } \\
\leftrightarrow \text { Offal weight }\end{array}$ & $0.5 \%$ & $\begin{array}{l}\text { Durrani et al. } \\
2006\end{array}$ \\
\hline
\end{tabular}


First Trial: 19-days

old broiler,

28-days of trial

Second Trial: 21-days

old broiler,

28-days of trial
Total 180 chicks in six dietary treatment: control diet, 500 ppm virginiamycin, $200 \mathrm{ppm}$ MOS, $0.1 \% \mathrm{TP}, 0.2 \% \mathrm{TP}, \& \mathrm{c} 0.3 \% \mathrm{TP}$

Total 144 chicks in three dietary treatments: $500 \mathrm{ppm}$ virginiamycin, 200 ppm MOS, \& 0.1\% TP $\uparrow$ Carcass weight compare to

$0.1 \%$ control
Samarasinghe et al., 2003 $\downarrow$ FCR \& coliform count com-

pared to control

$\leftrightarrow \mathrm{FI}$ in $0.1 \% \mathrm{TP}$ with other groups, BWG with virginiamycin \& MOS groups

Abbreviations: $\uparrow=$ increase; $\downarrow=$ decrease; $\leftrightarrow$ = similar effect; $-=$ no recommendation stated; BWG = Body Weight Gain; FI = Feed Intake; FCR = Feed Conversion Ratio; EPEI = European Production Efficiency Index; MQ = Meat Quality; CW = Carcass Weight; CSCI = Carcass Skin Color Index; TBARS = Thiobarbituric Acid Reactive Substance; TP = Turmeric Powder; MOS = Mannanoligosaccharide; CTC = Oxytetracycline; HSCAS = Hydrated Sodium Calcium Aluminosilicate

Table 2: Effect of turmeric powder on broiler performance and meat quality raised under challenge condition

\begin{tabular}{|c|c|c|c|c|}
\hline $\begin{array}{l}\text { Breeds and Duration of } \\
\text { Exposure }\end{array}$ & Methodology & Findings & $\begin{array}{l}\text { Recommended } \\
\text { TP Inclusion }\end{array}$ & References \\
\hline $\begin{array}{l}\text { 1-day-old Cobb-500 broiler, } \\
30 \text {-days of trial }\end{array}$ & $\begin{array}{l}\text { Total } 3000 \text { chicks in six } \\
\text { groups. Each group was } \\
\text { divided into two subgroups } \\
\text { fed either control or } 0.2 \% \\
\text { TP diets }\end{array}$ & $\downarrow$ FCR, C. perfringes counts & $0.2 \%$ & Ali et al. 2020 \\
\hline $\begin{array}{l}\text { 1-day-old Lohmann broiler, } \\
\text { 35-days of trial }\end{array}$ & $\begin{array}{l}\text { Total } 392 \text { chicks in four } \\
\text { dietary treatments: con- } \\
\text { trol, } 1 \% \text { acidified TP, } 1 \% \\
\text { acidified black pepper, } 1 \% \\
\text { acidified TP + } 1 \% \text { acidified } \\
\text { black pepper }\end{array}$ & $\begin{array}{l}\uparrow \text { Meat yellowness } \\
\downarrow \text { FCR, abdominal fat, } \\
\text { meat lightness, } \\
\leftrightarrow \text { FI, BWG, internal or- } \\
\text { gans, meat redness in } 1 \% \\
\text { TP \& control groups }\end{array}$ & $1 \%$ & $\begin{array}{l}\text { Sugiharto et al. } \\
2020\end{array}$ \\
\hline $\begin{array}{l}\text { 1-day-old male Cobb broiler, } \\
\text { 35-days of trial }\end{array}$ & $\begin{array}{l}\text { Total } 672 \text { chicks in } 4 \times 2 \\
\text { factorial design (TP level } \mathrm{x} \\
\text { S. typhimurium inoculation). } \\
\text { Levels of TP: control, } 1 \% \text {, } \\
2 \%, \& 3 \%\end{array}$ & $\begin{array}{l}\uparrow F I, \text { BWG, FCR, villus } \\
\text { height, crypt depth, } \\
\downarrow \text { FI \& BWG in } 3 \% \text { TP; } \\
\text { bacterial infection }\end{array}$ & $1 \%$ & $\begin{array}{l}\text { Nascimento et al. } \\
2019\end{array}$ \\
\hline $\begin{array}{l}\text { 1-day-old Ross } 308 \text { broiler, } \\
\text { 42-days of trial }\end{array}$ & $\begin{array}{l}\text { Total } 625 \text { chicks in } \\
\text { five treatments groups: } \\
\text { thermoneutral control, } \\
\text { heat-stressed control, } \\
\text { heat-stressed } 0.1 \% \text { betaine, } \\
\text { heat-stressed } 0.2 \% \text { TP, } \& \\
\text { heat-stressed } 0.1 \% \text { betaine } \\
+0.2 \% \mathrm{TP}\end{array}$ & $\begin{array}{l}\uparrow \mathrm{BWG}, \mathrm{FI} \text { compared to } \\
\text { heat-stressed control } \\
\downarrow \text { FCR, Mortality rate, } \\
\text { heterophil:lymphocyte } \\
\text { ratio compared to heat- } \\
\text { stressed control } \\
\leftrightarrow \text { BWG, FI, FCR in } \\
\text { betaine \& TP groups }\end{array}$ & $0.2 \%$ & $\begin{array}{l}\text { Akhavan-Salamat } \\
\text { and Ghasemi } 2016\end{array}$ \\
\hline $\begin{array}{l}\text { 1-day-old Ross } 308 \text { broiler, } \\
\text { 42-days of trial }\end{array}$ & $\begin{array}{l}\text { Total } 200 \text { chicks in four } \\
\text { treatment groups under } \\
\text { heat stress condition: con- } \\
\text { trol, } 0.5 \% \mathrm{TP}, 0.5 \% \text { cinna- } \\
\text { mon, } 0.25 \% \mathrm{TP}+0.25 \% \\
\text { cinnamon }\end{array}$ & $\begin{array}{l}\uparrow \mathrm{BWG}, \mathrm{FI} \\
\downarrow \mathrm{FCR}, \text { lipid peroxidation }\end{array}$ & $0.5 \%$ & $\begin{array}{l}\text { Baghban et al. } \\
2016\end{array}$ \\
\hline $\begin{array}{l}\text { 1-day-old Hubbard broiler, } \\
\text { 35-days of trial }\end{array}$ & $\begin{array}{l}\text { Total } 180 \text { chicks in six } \\
\text { dietary treatment: control, } \\
0.5 \% \mathrm{TP}, 1 \% \mathrm{TP}, 30 \mathrm{mg} \text { en- } \\
\text { dosulfan, } 30 \mathrm{mg} \text { endosulfan } \\
+0.5 \% \mathrm{TP}, 30 \mathrm{mg} \text { endosul- } \\
\text { fan }+1 \% \mathrm{TP}\end{array}$ & $\begin{array}{l}\uparrow \mathrm{FI}, \mathrm{BWG}, \mathrm{FCR}, \mathrm{CW}, \\
\text { detoxification } \\
\downarrow \text { Mortality }\end{array}$ & $0.5 \%$ & $\begin{array}{l}\text { Alagawany et al. } \\
2015\end{array}$ \\
\hline
\end{tabular}


1-day-old Ross 308 broilers, 42-days of trial
Total of 288 chicks in eight dietary treatments: negative control, positive control (vaccinated with ND HB1 \& Lasota, IB, \& IBD), \& positive control + different level of TP $(1 \%, 1.2 \%, 1.4 \%$, $1.6 \%, 1.8 \% \& 2 \%)$

1-day-old male Ross 308 broiler, 42-days of trial

Total 250 chicks in five treatment groups: thermoneutral control, heat-stressed control, heat-stressed 0.5\% TP, heat-stressed $0.5 \%$ cinnamon, \& heat-stressed $0.25 \%$ $\mathrm{TP}+0.25 \%$ cinnamon . Dietary treatments were given from 25 to 42 days

1-day-old male Ross $308 \quad$ Total 300 chicks in four broiler, 42-days of trial dietary treatments: control, $0.33 \% \mathrm{TP}$

\section{1-day-old broiler,} 42-days of trial

\section{Total 90 chicks in six treatment groups infected with Eimeria tenella. Two control groups (infected \& uninfected) \& four treat- ment groups (1.2\% salino- mycin sodium, $1 \% \mathrm{TP}, 2 \%$ TP, \& 3\% TP)}

1-day-old male Cobb broiler, 21-days of trial

Total 140 chicks in seven dietary treatments: control, $\downarrow$ BWG, FI, $\leftrightarrow$ FCR, antibody titer

Qasem et al. 2015 production, weight of lymphoid organs $\uparrow$ Dry matter of thigh

$\downarrow$ Meat lightness, lipid peroxidation $\leftrightarrow$ Meat redness \& yellowness meat, thigh $\mathrm{pH}$

$0.5 \%$

Kanani et al. 2013 $0.5 \%$ food grade TP, $0.5 \%$ HSCAS, 1 ppm aflatoxin $\mathrm{B}_{1}, 0.5 \% \mathrm{TP}+1 \mathrm{ppm}$ aflatoxin $\mathrm{B}_{1}, 0.5 \%$ HSCAS +1 ppm aflatoxin $\mathrm{B}_{1}, \&$ $0.5 \% \mathrm{TP}+0.5 \% \mathrm{HSCAS}+$ 1 ppm aflatoxin $B_{1}$ $\downarrow$ FCR, abdominal fat, liver weight, blood triglyceride $\leftrightarrow \mathrm{FI}, \mathrm{BWG}, \mathrm{CW}$, antibody titer production

$\downarrow$ Bloody feces, oocyst excretion $\leftrightarrow \mathrm{FI}, \mathrm{BWG}, \mathrm{FCR}$ in $3 \%$

TP, salinomycin \& uninfected groups Nouzarian et al. $\uparrow F I$, BWG, blood total protein \& cholesterol, $\downarrow$ Relative liver weight, liver peroxide $\leftrightarrow \mathrm{FCR}$

\section{$1 \%+$ HSCAS Gowda et al. 2008} Abbreviations: $\uparrow=$ increase; $\downarrow=$ decrease; $\leftrightarrow$ = similar effect; $-=$ no recommendation stated; BWG = Body Weight Gain; FI =
Feed Intake; FCR = Feed Conversion Ratio; EPEI = European Production Efficiency Index; MQ = Meat Quality; CW = Carcass Weight; CSCI = Carcass Skin Color Index; TBARS = Thiobarbituric Acid Reactive Substance; TP = Turmeric Powder; MOS = Mannanoligosaccharide; CTC = Oxytetracycline; HSCAS = Hydrated Sodium Calcium Aluminosilicate

\section{Antibacterial Property of Turmeric Powder} Turmeric and its derivatives have proven to have an antimicrobial property based on in vitro and in vivo trials. Reduction of Escherichia coli counts was observed by Ahlawat et al. (2018) by supplementing turmeric powder at $0.5 \%$ of the diet. A study by Nascimento et al. (2019) reported that $1 \%$ turmeric powder in the diet inhibits intestinal colonization of Salmonella typhimurium in infected chicks. Necrotic enteritis induced by Clostridium perfringens causes high mortality and problem in performance in poultry (Caly et al., 2015). Furthermore, coccidiosis caused by protozoan is one of the predisposing factors of necrotic enteritis (Adhikari et al., 2020). A recent study by Ali et al.
(2020) reported that dietary supplementation of turmeric powder at $0.2 \%$ was found to have an effective reduction of $C$. perfringens counts in the gut of broiler chicken. Additionally, protozoan under genus Eimeria can be controlled by turmeric powder (Abbas et al., 2010; Gogoi et al., 2019). The findings conclude that turmeric powder can be used to prevent necrotic enteritis and other intestinal diseases.

The reduction of bacterial counts might be due to the antimicrobial properties of the active components of turmeric. In vitro trials confirmed that curcumin is effective in controlling Streptococcus pyogenes, S. aureus, Acinetobacter iwoffi, Enterococcus faecalis, Pseudomonas aeruginosa, Salmonella 
enteritica, E. coli, Bacillus subtilis, and Klebsiella pneumoniae (Infante et al., 2014; Gunes et al., 2016; Adamczak et al., 2020). Boeder et al. (2018) reported that turmeric extract with high curcumin content have better anti-mycoplasma ( $M$. hominis, $M$. capricolum, $M$. genitalium, and $M$. pneumoniae) activity. Furthermore, $M$. gallisepticum which is the causative agent of chronic respiratory disease, can be controlled by combining nanoparticles of turmeric, zedoary, and garlic extracts (Handharyani et al., 2020).

The essential oil from turmeric can inhibit the growth of $E$. coli, P. aeruginosa, Bacillus cereus, Bacillus coagulans, Bacillus subtilis, and S. aureus, and Staphylococcus epidermitis (Negi et al., 1999; Goncalves et al., 2019; Kumar et al., 2020). Essien et al. (2015) discussed that the turmeric essential oil's significant antibacterial activity might be attributed to turmerone level. However, Marliyana et al. (2019) reported that pure ar-turmerone does not have antibacterial activity against $S$. aureus ATCC 25923, E. coli ATCC 25922, Klebsiella pneumonia ATCC 13883, and P. aeruginosa ATCC 27853. The authors stress that the essential oil's antibacterial activity might be due to the compounds' synergism instead of the pure compounds.

The antibacterial mechanisms of curcumin were reviewed by Zheng et al. (2020) and Kai et al. (2020). The authors discussed that it destroys bacteria by inhibiting the bacteria's quorum-sensing system, downregulation of bacterial gene expression, inhibition of SOS-induced responses, inhibition of cell division, and interfering protein synthesis by RNA disruption, disruption of the cell membrane, and induction of reactive oxygen species.

\section{Turmeric Powder versus Antimicrobial Growth Promoter}

Numerous studies recommending turmeric and its derivatives to use as an alternative to AGP in broiler chickens have shown significant improvement or similar performance with that of antibiotics. Attia et al. (2017) found significant improvement in feed conversion ratio (FCR) and European production index of Hubbard broiler when fed with $0.1 \%$ turmeric powder from day 1 to day 35 compared to control diet (no turmeric powder), a diet with $0.05 \%$ and $0.2 \%$ turmeric powder, a diet with $0.1 \%$ mannan oligosaccharide (MOS), and diet with $50 \mathrm{ppm}$ oxytetracycline (CTC). Samarasinghe et al. (2003) found no significant difference in feed intake, weight gain, and FCR between broiler chicken fed $0.1 \%$ turmeric powder, $200 \mathrm{ppm}$ MOS, and $500 \mathrm{ppm}$ virginiamycin. The author added, $0.2-0.3 \%$ turmeric powder improved protein and energy utilization. Ahlawat et al. (2018) compared the broiler chickens' performance fed different levels $(0.25 \%$, $0.5 \%, 0.75 \%$, and $1 \%$ ) of turmeric powder and unnamed antibiotics. The authors observed a significant difference in body weight gain at $0.5-75 \%$ and a significant difference in FCR at 0.5\%. Moreover, Abbas et al. (2010) found a similar coccidiostatic effect with that of salinomycin sodium $(0.024 \%$ of the diet) when $3 \%$ turmeric powder is added to the diet of Eimeria tenella infected broiler chicken. The nano-curcumin of turmeric was effective in controlling Eimeria species (Gogoi et al., 2019). The findings reported in those studies conclude that turmeric powder can replace certain antibiotics as a growth promoter, giving better or at least similar performance.

\section{Effect on Feed InTAKe}

Feed intake is a very critical and influential gauge in determining the performance of broiler chicken. Therefore, it is vital to determine the effect of feed ingredients on the animal's feed intake. Published studies regarding turmeric's impact on the feed intake of broilers vary from one experiment to another. Emadi and Kermanshashi (2006) reported $0.25-0.75 \%$ turmeric powder did not affect the feed intake of Ross broiler. This agrees with Mehala and Moorthy (2008) result where Vencobb broiler fed with 0.1-0.2\% turmeric powder did not influence feed intake. Also, Ahlawat et al. (2018) did not find a significant effect of $0.25-1 \%$ turmeric powder in feed intake. However, Daramola (2020) found a reduction of feed intake of broiler chicken (Arbor-acre) at $0.5 \%$ turmeric powder. Moreover, Qasem et al. (2015) reported adverse effects of turmeric powder in feed intake at a higher dose (1-2\% into the diet of Ross 308 broiler chicken).

Turmeric powder might improve feed intake when broiler chicken is under stress conditions. Akhavan-Salamat and Ghasemi (2016) reported an improvement in feed intake in Ross 308 broilers fed $0.2 \%$ turmeric powder raised under heat stress conditions. A similar finding was observed by Baghban et al. (2016) and Sadeghi and Moghaddam (2018) at 0.5\% turmeric powder. Cobb-500 broiler raised in humid subtropical climate had better feed intake fed $0.75 \%$ turmeric powder diet.

Turmeric can also alleviate the adverse effect of toxic contaminants in the diet. Alagawany et al. (2015) reported Hubbard broiler chicken exposed to endosulfan (30 ppm) increased feed intake fed $0.5-1 \%$ turmeric powder diet. Also, Cobb x Cobb broiler exposed to $1 \mathrm{ppm}$ aflatoxin slightly improved the performance and feed intake when turmeric powder is given at $0.5 \%$ (Gowda et al., 2008). Gholami-Ahangaran et al. (2015) reported that aflatoxin's toxic effect in the liver is mitigated by turmeric powder. Furthermore, Yarru et al. (2009) found that turmeric powder changes the expression of certain genes (antioxidant, biotransformation, and immune system) in the liver of chicken fed aflatoxin. 
An infection such as coccidiosis can adversely affect broiler chicken feed intake (Christaki et al., 2004). However, the Eimeria tenella infected chicken fed with 3\% turmeric powder in the diet would eat the same amount of non-infected chicken (Abbas et al., 2010). Nascimento et al. (2019) reported that 3\% turmeric powder in the diet adversely affected the feed intake even the chicken was inoculated with Salmonella typhimurium. The findings revealed that the inclusion of $1 \%$ was the effective dose without negatively affecting the feed intake.

\section{Effect on FCR And Body Weight Gain}

Numerous studies evaluated the effect of turmeric powder on the growth performance of broiler chicken. The variation of the findings might be due to several factors such as basal diets, growing duration, statistical design, breeds of broiler, the dosage of turmeric powder (Dono, 2013), and variation of the amount of active components ( $\mathrm{Li}$ et al., 2011). Kafi et al. (2017) observed improvement in harvest weight and FCR of Cobb-500 broilers when the commercial feed was supplemented with $0.75 \%$ turmeric powder. A recent study by Ekine et al. (2020) reported that $1 \%$ inclusion of turmeric powder in a corn-soybeanbased diet improved body weight gain and FCR of Ross broiler chicken without significant effect in blood Aspartate aminotransferase, Alanine transaminase, and lipid profile. Thirty-five days-old broilers supplemented with $0.5 \%$ turmeric powder improved body weight gain, FCR, dressing percentage, breast yield, and thigh yield (Durrani et al., 2006). Daramola (2020) reported an improvement in FCR and body weight gain of Arbor-acre broiler fed $0.5-1 \%$ sundried turmeric powder. However, Nouzarian et al. (2011) only found significant improvement of performance parameters in FCR when $0.33-1 \%$ oven-dried turmeric powder replaced corn in basal diet and fed to male Ross 308 broilers. An adverse effect of turmeric powder in body weight gain was observed by Qasem et al. (2015) when turmeric powder was given at $1-2 \%$ of the diet of vaccinated Ross 308 broiler chicken, however, the FCR was not affected.

The efficacy of turmeric was also tested in a challenging environment. For example, Ross broiler raised under heat stress conditions and fed with $0.5 \%$ turmeric powder in the diet had better body weight gain which was correlated to better feed intake (Baghban et al., 2016). Furthermore, Akhavan-Salamat and Ghasemi (2016) reported that Ross 308 fed with $0.2 \%$ turmeric powder gives similar performance to provided with $0.1 \%$ betaine in the diet. Recently, Ali et al. (2020) reported that Cobb-500 broilers fed with $0.2 \%$ turmeric powder improved FCR. Also, the mortality rate was reduced due to the reduction of Clostridium perfringens count in the gut.
The improvement of broiler chicken performance might be due to turmeric powder's antioxidant content (Hewlings and Kalma, 2017) and enhancement of antioxidant enzyme activity (Sadeghi and Moghaddam, 2018). It also reduces lipid peroxidation during stress condition, improvement in intestinal morphology (Sugiharto, 2020) which improve nutrient utilization, improvement in immune status (Isroli et al., 2017), antimicrobial properties (Nascimento et al., 2019; Ali et al., 2020) and improvement in gut ecology (Ahlawat et al., 2018).

\section{Effect on Meat Quality}

Food and Agriculture Organization (2014) defined meat quality based on its compositional quality, palatability, and nutritional quality. Supplementation of turmeric powder in the diet of broiler chicken was found to affect meat quality. Daneshyar et al. (2011) reported that supplementation of turmeric powder improves the meat quality of broiler chicken by increasing the crude protein and reducing triglycerides and saturated fatty acids of the meat. Urusan and Bolukbasi (2020) reported that 0.2-0.4\% turmeric powder in the diet increased the DHA content of the breast, and the inclusion of $0.6-0.8 \%$ decreased saturated fatty acids in thigh and breast meat. Kanani et al. (2013) reported that Ross 308 raised under heat stress conditions enhanced meat $\mathrm{pH}$ and color. Sugiharto et al. (2020) found the same result where broiler fed with $1 \%$ acidified turmeric powder had a lower meat lightness value compared to the control. Slightly high yellow pigmentation of the skin and low abdominal fat of the carcass was observed. Partovi et al. (2020) discussed that the changes in meat lightness are linked to the oxidation of phospholipid of the meat, which contributed to $\mathrm{pH}$ reduction. Turmeric contains curcuminoids, which are natural antioxidants (Pashtetsky et al., 2019) and are deposited in the skin and tissue when supplemented in the diet causing slight yellow pigmentation of the meat (Johanna et al., 2018). The meat's oxidation defense is improved by the amount of curcuminoid (Zhang et al., 2015; Partovi et al., 2019).

\section{CONCLUSION}

The incorporation of Phytogenic feed additives as an alternative to synthetic antibiotics is gaining popularity in recent years. It is usually incorporated into farm animals' diets to enhance flavor and palatability, resulting in improved production performance. Turmeric is one of the many medicinal herbs promising in agricultural products as feed additives in broiler diets. It contains a high level of beneficial phenolic compounds and terpenoids, and the main curcuminoids of the rhizome are curcumin, demethoxycurcumin, and bisdemethoxycurcumin. Turmeric powder has been recommended as an alternative to synthetic antibiotics without adverse effects on broiler chickens' 
growth performance, health, and economic traits. Also, turmeric powder as a feed supplement into broiler diets improves the chicken meat crude protein content and reduces triglycerides and saturated fatty acids. Moreover, the bioactive compounds in turmeric showed a broad spectrum of biological activities, including antibacterial, antiviral, anticoccidal, antiprotozoal, digestion absorption-enhancing effects, protection against toxins, and coccidiosis. The various effects of turmeric in broiler chickens might be due to the different levels of Cucurmin incorporated into the diet. Thus, standardization of turmeric powder based on Cucurmin level is recommended for commercialization.

\section{ACKNOWLEDGEMENT}

This review did not receive grants from any funding agency in the public, commercial or non-profit sectors.

\section{AUTHORS CONTRIBUTION}

The authors contributed equally to this review paper.

\section{CONFLICT OF INTEREST}

The authors declare that there is no conflict of interest.

\section{REFERENCES}

-Abbas RZ, Iqbal Z, Khan MN, Zafar MA, Zia MA (2010). Anticoccidial Activity of Curcuma longa L. in broilers. Braz. Arch. Boil. Technol., 53(1): 63-67. DOI: http://dx.doi. org/10.1590/S1516-89132010000100008

-Abdul A, Kuanar A, Joshi R, Sandeep IS, Mohanty S, Naik P, Mishra A,Nayak S (2016).Development of Prediction Model and Experimental Validation in Predicting the Curcumin Content of Turmeric (Curcuma longa L.). Front. Plant Sci., (7): 1-17. https://doi.org/10.3389/fpls.2016.01507

-Abou-Elkhair R, Ahmed HA, Selim S (2014). Effects of Black Pepper (Piper Nigrum), Turmeric Powder (Curcuma longa) and Coriander Seeds (Coriandrum Sativum) and Their Combinations as Feed Additives on Growth Performance, Carcass Traits, Some Blood Parameters and Humoral Immune Response of Broiler Chickens. Asian-australas. J. Anim. Sci., 27(6): 847-854. http://dx.doi.org/10.5713/ ajas.2013.13644

-Adamczak A, Ożarowski M, Karpiński TM (2020). Curcumin, a natural antimicrobial agent with strain-specific activity. Pharmaceuticals. 13(7): 1-12. https://doi.org/10.3390/ ph13070153

-Adhikari P, Kiess A, Adhikari R, Jha R (2020). An approach to alternative strategies to control avian coccidiosis and necrotic enteritis. J. Appl. Poult. Res., 29(2): 515-534. https://doi. org/10.1016/j.japr.2019.11.005

-Ahlawat PK, Dalal R, Sonu BS, Tewatia VS, Panwar, Sheoran N (2018). Antimicrobial Effect of Dietary Supplementation of Turmeric Powder in Intestine of Broilers. Int. J. Curr. Microbiol. Appl. Sci., 7(4): 2244-2251. https://doi. org/10.20546/ijcmas.2018.704.256
-Ahmadi F (2010). Effect of Turmeric Curcumin longa powder on performance, oxidative stress state and some of blood parameters in broilers fed on diets containing aflatoxin. Global Vet. (5): 312-317.

-Akhavan-Salamat H, Ghasemi HA (2016). Alleviation of chronic heat stress in broilers by dietary supplementation of betaine and turmeric rhizome powder: dynamics of performance, leukocyte profile, humoral immunity, and antioxidant status. Trop. Anim. Health Prod.,48(1): 181-8. https://doi.org/10.1007/s11250-015-0941-1

-Alagawany M, Ashour EA, Reda FM (2016). Effect of dietary supplementation of garlic (Allium sativum) and turmeric (Curcuma longa) on growth performance, carcass traits, blood profile and oxidative status in growing rabbits. Ann. Anim. Sci., 16(2): 489-505. https://doi.org/10.1515/aoas2015-0079

-Alawagany MM, Farag MR, Dhama K (2015). Nutritional and Biological Effects of Turmeric (Curcuma longa) Supplementation on Performance, Serum Biochemical Parameters and Oxidative Status of Broiler Chicks Exposed to Endosulfan in the Diets. Asian J Anim vet Adv., 10(2): 86-96. DOI: https://doi.org/10.3923/ajava.2015.86.96

-Ali M, Islam M, Zaman S (2020). Effects of Turmeric Powder on Clostridium Perfringens Load in Broiler Chickens. SAARC J. Agric. 18(1): 209-218. https://doi.org/10.3329/ sja.v18i1.48394

-Allen PC, Fetterer RH (2002). Recent advances in biology and immunobiology of Eimeria species and in diagnosis and control of infection with these coccidian parasites of poultry. Clin. Microbiol. Rev., (15): 58-65.

-Al-Sultan SI (2003). The effect of Curcuma longa turmeric on overall performance of broiler chickens. Int. J. Poult. Sci., (2): 351-353.

-Andrew R, Izzo AA (2017). Principles of pharmacological research of nutraceuticals. Br. J. Pharmacol., (174): 11771194.

-Ashraf K, Sultan S (2017). A comprehensive review on Curcuma longa Linn.: Phytochemical, pharmacological, and molecular study. Int. J. Green Pharm.,11(4): 681. http://dx.doi. org/10.22377/ijgp.v11i04.1343

-Attia AY, Al-Harthi AM, Hassan SS (2017). Turmeric (Curcuma longa Linn.) as a phytogenic growth promoter alternative for antibiotic and comparable to mannan oligosaccharides for broiler chicks. Rev. Mex. Cienc Pecu., 8(1): 11-21. https:// doi.org/10.22319/rmcp.v8i1.4309

- Baghban P,Daneshyar M, Najafi R (2016). Effects of Cinnamon (Cinnamomum zeylanicum) and Turmeric (Curcuma longa) Powders on Performance, Enzyme Activity, and Blood Parameters of Broiler Chickens Under Heat Stress. Poult. Sci. J., 4(1): 47-53.

- Boeder AM, Tenfen A, Siebert DA, Almeida CL, Firmo CRM, Scharf DR, Micke GA, Siminionatto EL, Cordovaand CMM, Guedes A (2018). Anti-mycoplasma activity of Curcuma longa extracts and an isolated compound, the curcumin. Revista Fitos. Rio de Janeiro. 12(2): 112-118. https://doi.org/10.5935/2446-4775.20180010

- Caly DL, D'Inca R, Auclair E, Drider D (2015). Alternatives to Antibiotics to Prevent Necrotic Enteritis in Broiler Chickens: A Microbiologist's Perspective. Front. Microbiol., (6): 1336. https://doi.org/10.3389/fmicb.2015.01336

- Choudhury D (2019). Study on the nutrient composition of local variety of turmeric (Curcuma longa). J. Pharm. Innov., 8(2): 205-207. 
- Christaki EPC, Florou-Paneri I, Giannenas M, Papazahariadou N. Botsoglou, Spais A (2004). Effect of a mixture of herbal extracts on broiler chickens infected with Eimeria tenella. Anim. Res., 53(2): 137-144. https://doi.org/10.1051/ animres:2004006

- Dalal R, Kosti D (2018). Turmeric powder as feed additive in laying hen A-review. J. Pharmacog. Phytother., 7(3): 26862689.

- Daneshyar M, Ghandkanlo MA, Bayeghra FS, Farhangpajhoh F, Aghaei M (2011). Effects of dietary turmeric supplementation on plasma lipoproteins, meat quality and fatty acid composition in broilers. S. Afr. J. Anim. Sci., 41(4): 420-428. http://dx.doi.org/10.4314/sajas.v41i4.13

-Daramola OT (2020). Growth performance and serum metabolites of broiler chickens fed turmeric (Curcuma longa) powder supplemented diets. Livest. Res. Rural., 32(12): http://www.lrrd.org/lrrd32/12/alaju32188.html

- Dono ND (2013). Turmeric (Curcuma longa Linn.) Supplementation as an Alternative to Antibiotics in Poultry Diets. Indonesian Bulletin Anim. Vet. Sci. 23(1): http:// dx.doi.org/10.14334/wartazoa.v23i1.958

-Dumaup HJJ, Ampode KMB (2020). Inclusion of Water Hyacinth Meal in Broiler Chicken Diets : Potential on the Production Performance and Cell-mediated Immunity. Int. J. Biosci., 17(6): 469-479.

-Durrani FR, Ismail M, Sultan A, Suhail SM, Chand N, Durrani Z (2006). Effect of Different Levels of Feed Added Turmeric (Curcuma longa) on the Performance of Broiler Chicks. Am. J. Agric. Biol. Sci., (1): 9-11.

- Ekine OA,Udoudo EF, George OS (2020). Influence of turmeric (Curcuma longa) as feed additive on the performance, serum enzymes and lipid profile of broiler chickens. Nigerian J. Anim. Sci., 22(2): 57-63.

-Emadi M, Kermanshahi H (2006). Effect of Turmeric Powder on Performance and Carcass Characteristics of Broiler Chickens. Int. J. Poult. Sci., 5(11): 1069-1072. https://doi. org/10.3923/ijps.2006.1069.1072

-Essien EE, Newby JS, Walker TM, Setzer WN (2015). Chemotaxonomic Characterization and in-Vitro Antimicrobial and Cytotoxic Activities of the Leaf Essential Oil of Curcuma longa Grown in Southern Nigeria. Med. 2(4): 340-349. https://doi.org/10.3390/medicines2040340

- Food and Agriculture Organization (2014). Meat Quality. Retrieved from: tinyurl.com/lnqqiy7b. January 14, 2021.

- Geethanjali A, Lalitha P, Jannathul Firdhouse M (20160. Analysis of Curcumin Content of Turmeric Samples from Various States of India. Int. J. Pharma Chem. Res., 2(1): 5562.

- Gholami-Ahangaran M, Rangsaz N, Azizi S (2015). Evaluation of turmeric (Curcuma longa) effect on biochemical and pathological parameters of liver and kidney in chicken aflatoxicosis, Pharm. Biol., 54(5): 780-787. https://doi.org/ 10.3109/13880209.2015.1080731

- Gogoi C, Sarma J, Barua CC, Tamuly S, Upadhyaya TN, Islam S, Sonowal J, Borthakur U, Banerjee DK, Barkathullah N (2019). Evaluation of nano-curcumin on experimentally induced coccidiosis in broiler chicks. Int. J. Chem. Stud., 7(3): 4514-4520.

- Gonçalves GMS, Barros PP, Silva GH, Fedes GR (2019). The essential oil of Curcuma longa rhizomes as an antimicrobial and its composition by CG-MS. Rev. Ciênc Med. 28(1), 1-10. http://dx.doi.org/10.24220/2318-0897v28n1a4389

- Gowda NKS, Ledoux DR, Rottinghaus GE, Bermudez AJ, Chen
YC (2008). Efficacy of turmeric (Curcuma longa), containing a known level of curcumin, and a hydrated sodium calcium aluminosilicate to ameliorate the adverse effects of aflatoxin in broiler chicks. Poult. Sci., 87(6): 1125-30. DOI: https:// doi.org/10.3382/ps.2007-00313

- Guetiya Wadoum RE, Zambou NF, Anyangwe FF, Njimou JR, Coman MM, Verdenelli MC, Cecchini C, Silvi S, Orpianesi C, Cresci A. Colizzi V (2016). Abusive use of antibiotics in poultry farming in Cameroon and the public health implications. Br. Poult. Sci., 57(4): 1-37. https://doi.org/10. 1080/00071668.2016.1180668

-Guil-Guerrero JL, Ramos L, Zúñiga Paredes JC, CarlosamaYépez M, Moreno C, Ruales P (2017). Effects of turmeric rhizome powder and curcumin on poultry production. A review. J. Anim. Feed Sci. 26:293-302. https://doi. org/10.22358/jafs/78511/2017

-Gunes H, Gulen D, Mutlu R, Gumus A, Tas T, Topkaya AE (2016).Antibacterialeffects ofcurcumin:Aninvitro minimum inhibitory concentration study. Toxicol Ind. Health. 32(2): 246-250. https://doi.org/10.1177/0748233713498458

-Handharyani E, Sutardi LN, Mustika AA, Andriani A, Yuliani S (2020). Antibacterial Activity of Curcuma longa (turmeric), Curcuma zedoaria (zedoary), and Allium sativum (garlic) Nanoparticle Extract on Chicken with Chronic Respiratory Disease Complex: In Vivo Study. E3S Web of Conf., (151): 01054. DOI: https://doi.org/10.1051/ e3sconf/202015101054

-Hewlings SJ, Kalman DS (2017). Curcumin: A Review of Its' Effects on Human Health. Foods. 6(10): 92. https://doi. org/10.3390/foods6100092

-Infante K, Chowdhury R, Nimmanapalli R, Reddy G (2014). Antimicrobial Activity of Curcumin Against Food-Borne Pathogens. VRI Bio. Med. Chem., 2(1): 12. https://doi. org $/ 10.14259 / \mathrm{bmc} . v 2 \mathrm{i} 1.102$

-Isroli I, Yudiarti T, Widiastuti E. Sugiharto S (2017). Effect of decocted turmeric on performance, hematological parameters and carcass traits of broiler chickens. J. Indones. Trop. Anim. Agric., 42(4): 263-269. https://doi. org/10.14710/jitaa.42.4.263-269

-Johannah NM, Ashil J, Balu MB, Krishnakumar IM (2018). Dietary addition of a standardized extract of turmeric (TurmaFEED ${ }^{\mathrm{TM}}$ ) improves growth performance and carcass quality of broilers. J. Anim. Sci. Techno., 60: 1-9. DOI: https://doi.org/10.1186/s40781-018-0167-7

-Kafi A, Uddin MN,Uddin MJ, Khan MMH, Haque ME (2017). Effect of Dietary Supplementation of Turmeric (Curcuma longa), Ginger (Zingiber officinale) and their Combination as Feed Additives on Feed Intake, Growth Performance and Economics of Broiler. Int. J. Poult. Sci., 16: 257-265. https:// doi.org/10.3923/ijps.2017.257.265

-Kai K, Bi W, Bo Y, Ye Y, Zhang D (2020). Curcumin-A Review of Its Antibacterial Effect. Biomed. J. Sci. Tech. Res., 26(1): 19585-19587. https://doi.org/10.26717/ BJSTR.2020.26.004286

- Kanani PB, Daneshyar M, Aliakbarlu J, Hamian F (2017). Effect of dietary turmeric and cinnamon powders on meat quality and lipid peroxidation of broiler chicken under heat stress condition. Vet. Res. Forum., 8(2): 163-169.

- Kiuchi F, Goto Y, Sugimoto N, Akao N, Kondo K, Tsuda Y (1993). Nematocidal activity of turmeric: Synergistic action of curcuminoids. Chem. Pharm. Bull., 41: 1640-1643. https://doi.org/10.1248/cpb.41.1640

- Kumar M, Kaur P, Garg R, Patil RK, Patil HC (2020). A study 
on antibacterial property of Curcuma longa - herbal and traditional medicine. Adesh Univ. J. Med. Sci. Res., 2(2), 103-108. https://doi.org/10.25259/AUJMSR_11_2020

-Landers TF, Cohen B, Wittum TE, Larson EL (2012). A review of antibiotic use in food animals: perspective, policy, and potential. Pub. Health Rep., 127: 4-22. https://doi. org/10.1177/003335491212700103

- Li S, Wei Y, Guangrui D, Ping W, Peiying Y, Bharat A (2011). Chemical composition and product quality control of turmeric (Curcuma longa L.). Faculty Publications. 2: 28-54.

-Lillehoj H, Liu Y, Calsamiglia S, Fernandez-Miyakawa M, Chi F, Cravens R, Oh S, Gay C (2018). Phytochemicals as antibiotic alternatives to promote growth and enhance host health. Vet. Res., 49: 76 .1-18. https://doi.org/10.1186/ s13567-018-0562-6

-Lopresti A (2018). The Problem of Curcumin and Its Bioavailability: Could Its Gastrointestinal Influence Contribute to Its Overall Health-Enhancing Effects. Adv. Nutr., 9(1): 41-50. https://doi.org/10.1093/advances/ nmx011

-Manyi-Loh C, Mamphweli S, Meyer E, Okoh A (2018). Antibiotic Use in Agriculture and Its Consequential Resistance in Environmental Sources: Potential Public Health Implications. Molecules. 23: 1-48. https://doi. org/10.3390/molecules23040795

- Marliyana SD, Wibowo FR, Wartono MW, Munasah G (2019). Evaluation of antibacterial activity of sesquiterpene Ar- Turmerone from Curcuma soloensis Val. rhizomes. IOP conf. ser., Mater. Sci. Eng., 578(1): 26-29. https://doi. org/10.1088/1757-899X/578/1/012060

- Mehala C, Moorthy M (2008). Production Performance of Broilers Fed with Aloe vera and Curcuma longa (Turmeric). Int. J. Poult. Sci. 7(9): 852-856. https://doi.org/10.3923/ ijps.2008.852.856

- Nascimento GM, Cervi RC, dos Santos JB, de Paiva Mota B, Leonídio ARA, Leandro NSM, Café MB, Andrade MA (2019). Effects of Curcuma longa on the intestinal health of chicks infected with Salmonella Typhimurium. R. Bras. Zootec., 48: 1-14. https://doi.org/10.1590/rbz4820180197

- Nasir Z, Grashorn MA (2010). Effects of Echinacea purpurea and Nigella sativa supplementation on broiler performance, carcass and meat quality. J. Anim. Feed Sci., 19: 94-104.

- Negi PS, Jayaprakasha GK, Rao LJM, Sakariah KK (1999). Antibacterial Activity of Turmeric Oil A Byproduct from Curcumin Manufacture. J. Agric. Food Chem., 47: 4297-4300.

- Nishiyama T, Mae T, Kishida H, Tsukagawa M, Mimaki Y, Kuroda M, Sashida Y, Takahashi K, Kawada T, Nakagawa K, Kitahara M (2005). Curcuminoids and sesquiterpenoids in Turmeric (Curcuma longa L.) suppress an increase in blood glucose level in type 2 diabetic KK-Ay mice. J. Agric. Food Chem., 53: 959-963.

- Nouzarian R, Tabeidian SA, Toghyani M, Ghalamkari G, Toghyani M (2011). Effect of turmeric powder on performance, carcass traits, humoral immune responses, and serum metabolites in broiler chickens. J. Anim. Feed Sci., 20(3): 389-400. https://doi.org/10.22358/jafs/66194/2011

- Ortserga DD., Andyar AC., Anthony TI (2008). Growth performance of growing rabbits fed graded levels of garlic (Allium sativum). Proc. 33rd Annual Conference of the Nigerian Society for Animal Production, Nigeria, Pp. 189191.

- Partovi R, Seifi S, Pabast M, Mohajer A, Sadighara P (2018).
Effect of dietary supplementation of nanocurcumin on oxidant stability of broiler chicken breast meat infected with Eimeria species. Vet. Res. Forum. 11(2): 159-163. https:// doi.org/10.30466/vrf.2018.86733.2125

- Pashtetsky V, Ostapchuk P, Il'yazov R, Zubochenko D, Kuevda $\mathrm{T}$ (2019). Use of antioxidants in poultry farming (review). IOP Conf. Ser.: Earth Environ. Sci. 341:1-9. https://doi. org/10.1088/1755-1315/341/1/012042

-Paul R, Gogoi B, Zaman K, Sharma HK (2016). Comparison of Curcumin Content of some Turmeric Samples Collected from Different Places of Northeast India. European J. Biomed. Pharm., 3(5): 440-445.

- Pawar H, Karde M, Mundle N, Jadhav P, Mehra K (2014). Phytochemical Evaluation and Curcumin Content Determination of Turmeric Rhizomes Collected From Bhandara District of Maharashtra (India). Med. Chem., 4(8): 588-591. https://doi.org/10.4172/2161-0444.1000198

- Prasad S, Aggarwal BB (2011). Turmeric, the Golden Spice: From Traditional Medicine to Modern Medicine. Herbal Medicine: Biomolecular and Clinical Aspects. 2nd edition. Boca Raton (FL): CRC Press/Taylor \& Francis; Chapter 13. Retrieved from: https://www.ncbi.nlm.nih.gov/books/ NBK92752/

-Qasem MAA, Alhajj MS, Ger El Nabi AR, Al-Murfarrej SI (2015). Effect of Turmeric Powder as a Dietary Supplement on Performance Indicators and Immune Responses in Broiler Chickens. J. Anim. Vet. Adv., 14(2): 30-35. https:// doi.org/10.36478/javaa.2015.30.35

-Sadeghi AA, Moghaddam M (2018). The effects of turmeric, cinnamon, ginger and garlic powder nutrition on antioxidant enzymes'status and hormones involved in energy metabolism of broilers during heat stress. Iran. J. Appl. Anim. Sci., 8: 125-130.

-Sadeghi GH, Karimi A, Padidar JSH, Azizi T, Daneshmand A (2012). Effects of cinnamon, thyme and turmeric infusions on the performance and immune response in of 1-to 21-dayold male broilers. Braz. J. Poult. Sci., 14: 15-20.

-Samarasinghe K, Wenk C, Silva KFST, Gunasekera JMDM (2003). Turmeric (Curcuma longa) Root Powder and Mannanoligosaccharides as Alternatives to Antibiotics in Broiler Chicken Diets. Asian-australas. J. Anim. Sci., 16(10): 1495-1500. https://doi.org/10.5713/ajas.2003.1495

- Soni KB, Lahiri M, Chackradeo P, Bhide SV, Kuttan R (1997). Protective effect of food additives on aflatoxin-induced mutagenicity and hepatocarcinogenicity. Cancer Lett., 115: 129-133.

- Sugiharto S, Pratama AR, Yudiarti T, Wahyuni HI, Widiastuti E, Sartono TA (2020). Effect of acidified turmeric and/or black pepper on growth performance and meat quality of broiler chickens. Int. J. Vet. Sci. Med., 8(1): 85-92. DOI: https://doi.org/10.1080/23144599.2020.1830691

- Sugiharto S (2020). Alleviation of heat stress in broiler chicken using turmeric (Curcuma longa) - a short review. J. Anim. Behav. Biometereol. 8: 215-222. https://doi.org/10.31893/ jabb. 20028

- Tanzeela N, Iqbal M, Raza A, Safdar M, Iftikhar F, Waheed M (2015). Turmeric: A Promising Spice for Phytochemical and Antimicrobial Activities. Am. Eurasian J. Agric. Environ. Sci., 15(7): 1278-1288. https://doi.org/10.5829/idosi. aejaes.2015.15.7.9528

-Urusan H, Bolukbasi C (2020). The Influence of Turmeric Powder (Curcuma longa) on Fatty Acid Composition and Shelf Life of Broiler Chicken Meat. Alinteri J. Agr. Sci., 
35(1): 29-35. https://doi.org/10.28955/alinterizbd.737995

-Van den Bogaard AE, Stobberingh EE (2000). Epidemiology of resistance to antibiotics Links between animals and humans. Int. J. Antimicrob. Agents. 14: 327-335.

-WHO (World Health Organization) (2012). The Evolving Threat of Antimicrobial Resistance. Options for Action. WHO. Geneva (Switzerland).

- Yang PA, Choct M (2009). Dietary modulation of gut microflora in broiler chickens: A review of the role of six kinds of alternatives into feed antibiotics. Worlds Poult. Sci. J., 65: 97-114.

- Yarru LP, Settivari RS, Gowda NKS, Antoniou E, Ledoux DR, Rottinghaus GE (2009). Effects of turmeric (Curcuma longa) on the expression of hepatic genes associated with biotransformation, antioxidant, and immune systems in broiler chicks fed aflatoxin. Poult. Sci., 8: 2620-2627.https:// doi.org/10.3382/ps.2009-00204

-Zhang JF, Bai KW, Su WP, Wang, AA, Zhang LL, Huang KH, Wang T (2018). Curcumin attenuates heat-stress-induced oxidant damage by simultaneous activation of GSHrelated antioxidant enzymes and Nrf2-mediated phase II detoxifying enzyme systems in broiler chickens. Poult. Sci., 97(4): 1209-1219. https://doi.org/10.3382/ps/pex408

-Zheng D, Huang C, Huang H, Zhao Y, Khan MRU, Zhao H, Huang L (2020). Antibacterial Mechanism of Curcumin: A Review. Chem. Biodiver. 17(8): 1-13. https://doi. org/10.1002/cbdv.202000171 